\title{
CENTRAL COMPOSITE DESIGN FOR OPTIMIZING EXTRACTION OF EGCG FROM GREEN TEA LEAF (CAMELLIA SINENSIS L.)
}

\section{EKA INDRA SETYAWAN ${ }^{1}$, ERNA PRAWITA SETYOWATI ${ }^{2}$, ABDUL ROHMAN ${ }^{3}$, AKHMAD KHARIS NUGROHO ${ }^{4 *}$}

1Department of Pharmacy, Faculty of Mathematics and Natural Science, University of Udayana, Bali, Indonesia, ${ }^{2}$ Departement of Pharmaceutical Biology, Faculty of Pharmacy, Gadjah Mada University, Yogyakarta, Indonesia, ${ }^{3}$ Departement of Pharmaceutical Chemistry, Faculty of Pharmacy, Gadjah Mada University, Yogyakarta, Indonesia, ${ }^{4}$ Departement of Pharmaceutics, Faculty of Pharmacy, Gadjah Mada University, Yogyakarta, Indonesia

Email: a.k.nugroho@ugm.ac.id

Received: 20 Aug 2018, Revised and Accepted: 21 Sep 2018

ABSTRACT

Objective: This study was intended to optimize the extraction condition using central composite design.

Methods: Central composite cesign with three independent variables, namely water temperature, brewing time, and brewing number were used to obtain the optimum extraction condition. Two dependent variables, namely yield of extraction and epigallocatechingallate level were used as a response parameter. Epigallocatechin gallate level was determined by using high-performance liquid chromatography method.

Results: Extraction yield was varied from $0.30 \mathrm{~g}$ to $0.72 \mathrm{~g}$. All variables, namely water temperature, brewing time, and brewing number were able to increase the extraction yield. Epigallocatechingallate level was varied from $190.23 \mathrm{mg} / \mathrm{g}$ to $301.74 \mathrm{mg} / \mathrm{g}$. Water temperature, brewing time, and both interaction were able to increase the epigallocatechin gallate level in green tea extract.

Conclusion: Optimum extraction condition was shown using hot water at a temperature of $95{ }^{\circ} \mathrm{C}$ for 20 min and two-times infusions. The condition obtained extraction yield and epigallocatechingallate of $0.70 \mathrm{~g}$ and $286.87 \mathrm{mg} / \mathrm{g}$ dry weight, respectively.

Keywords: Green tea, Extraction, Epigallocatechingallate, Optimization, Central composite design

(C) 2018 The Authors. Published by Innovare Academic Sciences Pvt Ltd. This is an open access article under the CC BY license (http://creativecommons.org/licenses/by/4.0/) DOI: http://dx.doi.org/10.22159/ijap.2018v10i6.29245

\section{INTRODUCTION}

Tea (Camellia sinensis L.) is derived from China and it was known for several thousand years ago [1]. Green tea is widely used as a healthy beverage $[2,3]$. The health merits related to green tea consumption have been associated with the epigallocatechingallate (EGCG) compound. EGCG has a broad spectrum of biological activities as well as, anticancer, antioxidant, antibacterial, and antimutagenic [4, 5]. Green tea also contains caffeine, theophylline, theobromine and phenolic acids like gallic acid [6, 7]. The green tea compounds vary depending on climate, seasons, tea variety, and age of leaf [1].

The fabrication method of green tea beverage varies in the whole world. In Japan, green tea leaves are brewed using hot water for two minutes and prepare them for two-three infusions. The Chinese are mostly preparing green tea leaves by brewing in hot water (70-80 ${ }^{\circ} \mathrm{C}$ ) and usually repeatedly brewed seven times. However, the most common way is steeping green tea leaves using a hot water at the temperature at $70-100{ }^{\circ} \mathrm{C}$ for $1-20 \mathrm{~min}$ [7-9]. The development of green tea as a pharmaceutical product needs a proper extraction procedure. Many factors during extraction procedure, specifically solvents, time, temperature and ratio of liquid-solid determine the efficacy of extract [10-13]. Consequently, optimization of extraction condition is needed to maximize the green tea efficacy.

Several studies have been declared in optimization extraction of green tea including a comparison of some extraction method of Turkish green tea [6]. Optimizing process of green tea extraction using hot water [9]. Influence of green tea preparation on the bioactive compounds [14]. Although previous study [1, 6, 9, 14] has identified several factors that affect the effectiveness of extraction using a water-solvent (temperature, time, water ratio, tea particle size, and $\mathrm{pH}$ ) but not a single publication has investigated and reported the application of experimental design of central composite design (CCD) on the optimizing process of green tea extraction. The design of experimental (DoE) exhibits several advantages including maximizing process knowledge with the minimum use of resources, provide accurate information in the most efficient way possible, identify factor interactions, allow the prediction of the process behavior within the design space, enable the optimization of critical quality attributes through appropriate selection of critical process parameters setting [15]. Therefore, this study was intended to optimize the extraction condition namely water temperature, brewing time, and brewing number to get the maximum level of extraction yield and EGCG from green tea leaf using CCD.

\section{MATERIALS AND METHODS}

\section{Materials}

A dried sample of green tea was purchased from PT. Mitra Kerinci (West Sumatera, Indonesia). EGCG 95\% was purchased from SigmaAldrich (Singapore). Methanol, acetonitrile, and ortho-phosphate acid were purchased from Merck (Germany).

\section{Instrumentation and software}

The stipulation of the EGCG level in green tea extract was carried out using a high-performance liquid chromatograhy (HPLC) system equipped with Smart-Line pump 1000 V7603, UV detector (SmartLine 2500 A5140), injector (Rheodyn Loop A135), Eurosphere C18 column $(250 \times 4.6 \mathrm{~mm}$, i. d $5 \mu \mathrm{m})$. The mobile phase $(0.1 \%$ orthophosphoric acid: water: acetonitrile: methanol with a ratio of 14:7:3:1 v/v/v/v), flow rate $1.2 \mathrm{ml} / \mathrm{min}$. The mobile phase was set at $\mathrm{pH} 4.00$ by buffering with triethylamine. Chromgate software version 3.1 for data analysis. DoE was computed and analyzed applying Design-Experts ${ }^{\circledR}$ software 7.1.5.

\section{Green tea extract preparation}

A single step and multiple step extraction were applied to prepare a green tea extract. $10 \mathrm{~g}$ dried green tea[6] were brewed in $250 \mathrm{ml}$ hot water with a different temperature and time by following the CCD design (table 1). The solution was chilled in cold water for $10 \mathrm{~min}$. $100 \mathrm{ml}$ of ethyl acetate was used to separated a non-polar compounds. A water bath was used to evaporate an ethyl acetate and the yield was accurately weighed. While the multiple step extraction, samples were brewed two-times on the same conditions with $150 \mathrm{ml}$ of hot water and continued in $100 \mathrm{ml}$ of hot water. 


\section{Quantitation of EGCG from green tea extract}

The extracts $(10 \mathrm{mg})$ were disolve in mobile phase $(10 \mathrm{ml})$ and sonicated for $15 \mathrm{~min}$. A nylon membrane $(0.45 \mu \mathrm{m})$ was used to filter a mixture and sample $(20 \mu \mathrm{l})$ was injected into a port. Analytes were detected at a wavelength of $280 \mathrm{~nm}$ [16-19].

\section{Method validation of HPLC system}

The system suitability test was performed by injecting an analytes at a concentration of $100 \mathrm{ppm}$ for six-times. The validation process was carried out by appraising various criteria, namely linearity, selectivity, accuracy, precision limit of detection (LoD), and limit of quantification (LoQ) [20].

\section{Experimental design for CCD}

A CCD with three factors (two numerical factors and one categorical factor) and five levels are selected for the optimization process. The factors were coded at five levels $(-\alpha,-1,0,1, \alpha)$. An $\alpha$-value is determined by the factor number and can be calculated by the following equation: $\alpha=2^{(\mathrm{k}-\mathrm{p}) / 4}$
For two factors, it is 1.41 . The number of the experiment can be calculated by the following equation:

$$
\mathrm{N}=\mathrm{k}^{2}+2 \mathrm{k}+\mathrm{Cp}
$$

Where $\mathrm{k}$ is the factor number and $\mathrm{Cp}$ is the replicates number of the central point[21]. Water temperature (A), brewing time (B), and brewing number $(\mathrm{C})$ were selected for independent variables. Both the yield extraction $\left(\mathrm{Y}_{1}\right)$ and EGCG level $\left(\mathrm{Y}_{2}\right)$ were chosen in response. ANOVA was used to analyze the level of statistical significance of the predicted model. The suitability of the model prediction to the response was assesed with the coefficient determination of adjusted r-square (Adj. $\mathrm{R}^{2}$ ), predicted $\mathrm{r}$-square (Pred. $\mathrm{R}^{2}$ ), and predicted residual sum of square (PRESS).

\section{RESULTS AND DISCUSSION}

\section{Validation method}

The \% relative standard deviation (\% RSD) of peak area and retention time was obtained $<2 \%$ (table 1 ).

Table 1: System suitability test of EGCG $(n=6)$

\begin{tabular}{lllll}
\hline Replication & tR (min.) & Asymetry USP & Width USP & Plates USP \\
\hline 1 & 17.70 & 1.082 & 1.05 & 16406.03 \\
2 & 17.80 & 1.071 & 1.06 & 16618.00 \\
3 & 17.90 & 1.065 & 1.07 & 17395.34 \\
4 & 17.71 & 1.109 & 1.06 & 16886.00 \\
5 & 17.72 & 1.107 & 1.04 & 17361.20 \\
6 & 17.72 & 1.098 & 1.08 & 16937.67 \\
Mean & 17.80 & 1.07 & 1.06 & 4155 \\
SD & 0.10 & 0.01 & 0.01 & 4106 \\
\%RSD & 0.01 & 0.01 & 0.01 & 4147 \\
\end{tabular}

Selectivity was assessed from the resolution for each chromatogram. The chromatogram separation obtained resolution (Rs) value of $>2$ (Rs $\geq 2$ ) (fig. 1 ) showing that HPLC was selective enough.
The linearity of EGCG was determined by coefficient correlation ( $\mathrm{r}$ value). The concentration used were $5,10,20,30,40,50 \mathrm{ppm}$. The equation of the calibration curve was $y=21254 x-111.9$. The calibration curve showed a good linearity with a r-value of 0.998 .

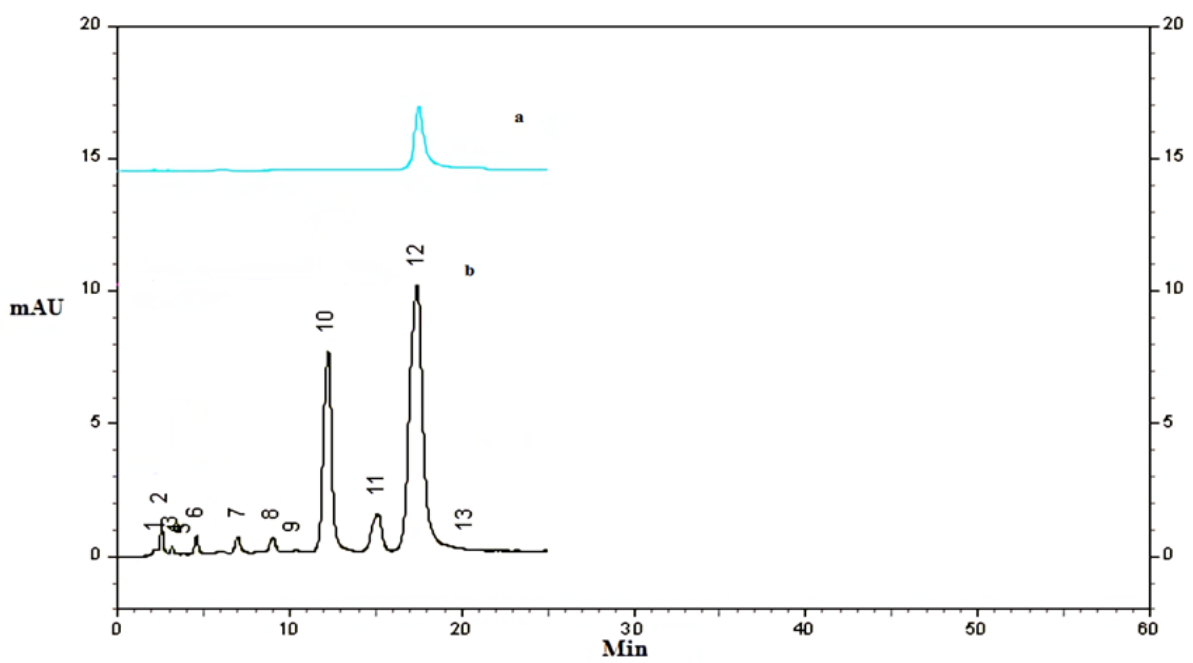

Fig. 1: HPLC chromatogram of EGCG standard (a) and green tea extract (b)

From the linear regression, LoD and LoQ were determined as:

$$
\operatorname{LoD}=\frac{3.3 \mathrm{x}^{\mathrm{Sy}} / \mathrm{x}}{\mathrm{b}}, \mathrm{LoQ}=\frac{10 \mathrm{x} \mathrm{Sy} / \mathrm{x}}{\mathrm{b}}, \mathrm{Sy} / \mathrm{x}=\sqrt{\frac{\overline{2(\mathrm{y} 1-\mathrm{yc}) 2}}{\mathrm{n}-2}}
$$

LoD and LoQ value obtained was $1.07 \mathrm{ppm}$ and $3.57 \mathrm{ppm}$, respectively. The accuracy of the HPLC method was performed by a standard addition method in which sample extract was spiked with EGCG standard solutions with a concentration of 10 ppm, $20 \mathrm{ppm}$, and $30 \mathrm{ppm}$ and the recovery was determined. The percentage recovery of EGCG obtained was a range of $98.2 \%$ $101.8 \%$. The precision of HPLC was analyzed by repeatability test (intra-day precision) by analysis six replicated of sample extract was spiked with EGCG standard solutions with a concentration of $10 \mathrm{ppm}, 20 \mathrm{ppm}$, and $30 \mathrm{ppm}$ and \% RSD were determined. The \% RSD of EGCG obtained were a range of $1 \%$ $2 \%$. 


\section{Experimental design}

To maximize the yield of extraction and EGCG level, we have investigated the effect of three extraction variables, namely water temperature, brewing time, and brewing number. Hot water was selected as a solvent because it provides the highest extract yield and EGCG compared to others [6]. The selected temperature was range from $70-100{ }^{\circ} \mathrm{C}$, based on the empirical experience of teaconsuming countries. Higher temperature results in EGCG instability $[4,22,23]$ and epimerization EGCG becomes trans-epimer (-)gallocatechingallate (GCG) and it is reversible [24]. The water temperature ranges are the optimum conditions, under this conditions the epimerization process can be controlled [25]. The previous study [23] showed that brewing time also affects on the epimerization process of catechin. The extraction process more than 20 min will decrease the EGCG levels and lead to the degradation process and it is characterized by increased levels of GCG [24, 26]. Therefore, in this study the brewing time is limited to $20 \mathrm{~min}$.

We have investigated a multiple step extraction (brewing number) where the rest material from the first brewing was extracted again with the same conditions. Based on the previous study [1] the extraction yields drastically decreased while the content of major catechin increased. The decreasing in the extraction yield due to the degradation process of an important component in green tea. In this study, the brewing number is limited to two-times to get the optimum condition.

\section{Yield of extraction}

The results showed that the extraction yield was varied from $0.30 \mathrm{~g}$ to $0.72 \mathrm{~g}$ (table 2).

Table 2: CCD for the independent variables and their responses $(n=18)$

\begin{tabular}{|c|c|c|c|c|c|c|}
\hline \multirow[t]{3}{*}{ Std } & \multirow[t]{3}{*}{ Run } & Factor A & Factor B & Factor C & Response $\left(\mathrm{Y}_{1}\right)$ & Response $\left(\mathrm{Y}_{2}\right)$ \\
\hline & & Water temp & Brewing time & Brewing number & Yield & EGCG \\
\hline & & ${ }^{\circ} \mathrm{C}$ & $\min$ & & G & mg/g dry weight \\
\hline 1 & 14 & 75.00 & 5.00 & Level 1 of $\mathrm{C}$ & 0.36 & 301.47 \\
\hline 2 & 2 & 95.00 & 5.00 & Level 1 of $\mathrm{C}$ & 0.56 & 196.30 \\
\hline 3 & 16 & 75.00 & 20.00 & Level 1 of $\mathrm{C}$ & 0.47 & 201.57 \\
\hline 4 & 8 & 95.00 & 20.00 & Level 1 of $\mathrm{C}$ & 0.69 & 293.24 \\
\hline 5 & 1 & 70.86 & 12.50 & Level 1 of $C$ & 0.46 & 240.24 \\
\hline 6 & 3 & 99.14 & 12.50 & Level 1 of $\mathrm{C}$ & 0.58 & 275.06 \\
\hline 7 & 9 & 85.00 & 1.89 & Level 1 of $\mathrm{C}$ & 0.30 & 245.80 \\
\hline 8 & 15 & 85.00 & 23.11 & Level 1 of $\mathrm{C}$ & 0.59 & 235.22 \\
\hline 9 & 6 & 85.00 & 12.50 & Level 1 of $\mathrm{C}$ & 0.55 & 207.49 \\
\hline 10 & 13 & 75.00 & 5.00 & Level 2 of $\mathrm{C}$ & 0.49 & 271.82 \\
\hline 11 & 5 & 95.00 & 5.00 & Level 2 of C & 0.56 & 190.23 \\
\hline 12 & 11 & 75.00 & 20.00 & Level 2 of C & 0.48 & 242.49 \\
\hline 13 & 4 & 95.00 & 20.00 & Level 2 of $\mathrm{C}$ & 0.64 & 294.24 \\
\hline 14 & 10 & 70.86 & 12.50 & Level 2 of C & 0.59 & 238.14 \\
\hline 15 & 12 & 99.14 & 12.50 & Level 2 of C & 0.72 & 278.31 \\
\hline 16 & 17 & 85.00 & 1.89 & Level 2 of $\mathrm{C}$ & 0.44 & 243.47 \\
\hline 17 & 7 & 85.00 & 23.11 & Level 2 of $\mathrm{C}$ & 0.74 & 214.85 \\
\hline 18 & 18 & 85.00 & 12.50 & Level 2 of C & 0.63 & 179.81 \\
\hline
\end{tabular}

The experimental results can be illustrated by the following linear equations:

$\mathrm{Y} 1=0.55+0.063(\mathrm{~A})+0.072(\mathrm{~B})+0.041(\mathrm{C})$

The actual value and model prediction value of the yield showed a good correlation (fig. 2a). Based on the ANOVA analysis, the linear equation has a p-value of $0.0002(<0.05)$ indicating that the equation model is significant. The model selection focuses on PRESS, Adj. $\mathrm{R}^{2}$ and
Pred. $\mathrm{R}^{2}$ value (table 3 ). The PRESS statistic illustrates how good the model fits the data. The PRESS values hould be small relative to the other models under consideration. Adj. $\mathrm{R}^{2}$ is a measure of the amount of variation about the mean explained by the model. Pred. $\mathrm{R}^{2}$ is a measure to see how good the resulting models predict the observed value. The Adj. $\mathrm{R}^{2}$-and Pred. $\mathrm{R}^{2}$ should be within approximately 0.20 of each other to be in "reasonable agreement." If they are not, there may be a problem with either the data or the model.
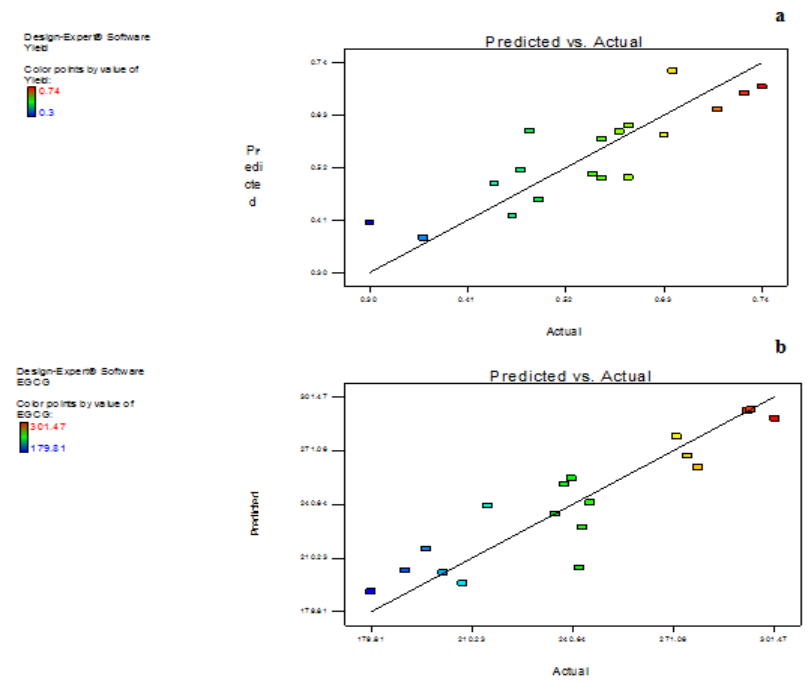

Fig. 2: Correlation between actual value and predicted value of extraction yield (a), correlation between actual and predicted value of EGCG level (b) 
Table 3: Model summary statistic of the extraction yield extraction yield

\begin{tabular}{llllll}
\hline Source & $\begin{array}{l}\text { Std. } \\
\text { Dev. }\end{array}$ & R-squared & Adj. R-squared & Pred. R-squared & PRESS \\
\hline Linear & 0.067 & 0.736 & 0.6794 & 0.5545 & 0.11 \\
2FI & 0.072 & 0.7569 & 0.6244 & 0.2918 & 0.17 \\
Quadratic & 0.070 & 0.8157 & 0.6518 & 0.2827 & 0.17 \\
Cubic & 0.071 & 0.9142 & 0.6353 & + & Aliased \\
\hline
\end{tabular}

The results of the ANOVA analysis, factors $\mathrm{A}, \mathrm{B}$, and $\mathrm{C}$ had a significant effect (table 4). The factors A, B, and C had a p-value of $0.0021,0.0008$, and 0.0221 , respectively. The model showed that the factors $\mathrm{A}, \mathrm{B}$, and $\mathrm{C}$ had a positive effect on the extraction yield indicating an increase in these factors, extraction yield increases (fig. 3a). It is because the cell wall becomes more penetrable for the solvent to penetrate the membrane and the constituents solubility is increase $[9,27,28]$. The maximum extraction yield is shown by using water temperature at $95{ }^{\circ} \mathrm{C}$ for $20 \mathrm{~min}$ with two-times brewing.

Table 4: Analysis of variance (ANOVA) of the extraction yield

\begin{tabular}{|c|c|c|c|c|c|c|}
\hline \multicolumn{7}{|c|}{ Yield ( $\left.Y_{1}\right)$} \\
\hline \multicolumn{7}{|c|}{ ANOVA for response surface linear model } \\
\hline \multicolumn{7}{|c|}{ Analysis of variance table [partial sum of squares-type III] } \\
\hline Source & $\begin{array}{l}\text { Sum of } \\
\text { Squares }\end{array}$ & df & $\begin{array}{l}\text { Mean } \\
\text { Square }\end{array}$ & $\begin{array}{l}\text { F } \\
\text { Value }\end{array}$ & $\begin{array}{l}\text { p-value } \\
\text { Prob>F }\end{array}$ & \\
\hline Model & 0.170 & 3 & 0.058 & 13.01 & 0.0002 & significan \\
\hline A-Water temp. & 0.063 & 1 & 0.063 & 14.09 & 0.0021 & \\
\hline B-Brewing time & 0.082 & 1 & 0.082 & 18.32 & 0.0008 & \\
\hline C-Brewing number & 0.030 & 1 & 0.030 & 6.63 & 0.0221 & \\
\hline Residual & 0.063 & 14 & 4.47E-03 & & & \\
\hline Cor Total & 0.240 & 17 & & & & \\
\hline
\end{tabular}

\section{EGCG level}

The results showed that the EGCG level was varied from 190.23 $\mathrm{mg} / \mathrm{g}$ to $301.74 \mathrm{mg} / \mathrm{g}$ (table 2). The experimental results can be illustrated by the following quadratic equations:
$\mathrm{Y} 2=193.65+3.92(\mathrm{~A})+1.02(\mathrm{~B})-2.39(\mathrm{C})+41.27(\mathrm{~A})(\mathrm{B})-0.55(\mathrm{~A})(\mathrm{C})+3.26(\mathrm{~B}) \mathrm{C})+32.78\left(\mathrm{~A}^{2}\right)+21.23\left(\mathrm{~B}^{2}\right)$ Based on the ANOVA analysis the prediction model has a p-value of $0.0088(<0.05)$. The coefficient determination of Adj. $\mathrm{R}^{2}$ and Pred. $\mathrm{R}^{2}$ was of 0.6874 and 0.3434 with a PRESS value of 16066.58 (table 5).

Table 5: Model summary statistic of the EGCG

\begin{tabular}{|c|c|c|c|c|c|c|}
\hline \multicolumn{7}{|l|}{ EGCG level } \\
\hline \multirow[t]{2}{*}{ Source } & Std. & R-Squared & Adj. R-Squared & Pred. R-Squared & PRESS & \\
\hline & Dev & & & & & \\
\hline Linear & 41.49 & 0.0149 & -0.1962 & -0.5989 & 39125.1 & \\
\hline 2FI & 30.60 & 0.5790 & 0.3493 & 0.0644 & 22892.9 & \\
\hline Quadratic & 21.21 & 0.8345 & 0.6874 & 0.3434 & 16066.6 & Suggested \\
\hline Cubic & 13.92 & 0.9683 & 0.8655 & + & Aliased & \\
\hline
\end{tabular}

It shows that the experimental model was the best fit using quadratic equations. In this case, the prediction model terms are significant. The actual value and model prediction value of the EGCG showed a good correlation (fig. 2b). There were only three factors contribute significantly toward the EGCG level, namely $\mathrm{AB}, \mathrm{A}^{2}$, and $\mathrm{B}^{2}$. This factor has p-value of $0.0004,0.0047$, and 0.0390 , respectively (table 6).

Table 6: Analysis of variance (ANOVA) of the EGCG

\begin{tabular}{|c|c|c|c|c|c|c|}
\hline \multirow{2}{*}{\multicolumn{7}{|c|}{$\begin{array}{lc}\text { Response } 2 & \text { EGCG }\left(\mathrm{Y}_{2}\right) \\
\text { ANOVA for response surface quadratic model }\end{array}$}} \\
\hline & & & & & & \\
\hline \multicolumn{7}{|c|}{ Analysis of variance table [partial sum of squares-type III] } \\
\hline \multirow[t]{2}{*}{ Source } & Sum of & df & Mean & $\mathbf{F}$ & p-value & \\
\hline & Squares & & Square & Value & Prob $>F$ & \\
\hline Model & 20419.30 & 8 & 2552.41 & 5.67 & 0.0088 & significant \\
\hline A-Water temp. & 245.80 & 1 & 245.80 & 0.55 & 0.4787 & \\
\hline B-Brewing time & 16.57 & 1 & 16.57 & 0.037 & 0.8521 & \\
\hline C-Brewing number & 102.87 & 1 & 102.87 & 0.23 & 0.6440 & \\
\hline $\mathrm{AB}$ & 13627.40 & 1 & 13627.4 & 30.28 & 0.0004 & \\
\hline $\mathrm{AC}$ & 4.81 & 1 & 4.81 & 0.011 & 0.9199 & \\
\hline $\mathrm{BC}$ & 169.83 & 1 & 169.83 & 0.38 & 0.5542 & \\
\hline$A^{2}$ & 6250.73 & 1 & 6250.73 & 13.89 & 0.0047 & \\
\hline $\mathrm{B}^{2}$ & 2621.33 & 1 & 2621.33 & 5.83 & 0.0390 & \\
\hline Residual & 4050.07 & 9 & 450.01 & & & \\
\hline Cor Total & 24469.40 & 17 & & & & \\
\hline
\end{tabular}


The quadratic equation above indicates that with an increasing factor $\mathrm{A}^{2}, \mathrm{~B}^{2}$, and interaction between A and B, EGCG level increases (fig. 3b). It was contradicted with factor C, EGCG has not been released completely in the first infusion[29]. The extraction temperature over $80{ }^{\circ} \mathrm{C}$ lead apolimerization and epimerization reaction[23]. The highest level of EGCG is shown by using water temperature at $75^{\circ} \mathrm{C}$ for 5 min with two-times brewing.

\section{Optimization}

The optimization process was performed by establishing the highest level of extraction yield and EGCG. The optimum conditions are based on the resulting desirability value. Desirability is an objective function that ranges from zero outside of the limits to one at the goal. The numerical optimization finds a point that maximizes the desirability function. The characteristics of a goal may be altered by adjusting the weight or importance. For several responses and factors, all goals get combined into one desirability function. The value is completely dependent on how closely the lower and upper limits are set relative to the actual optimum. The goal of optimization is to find a good set of conditions that will meet all the goals $[15,30,31]$. The results generated nine solutions for the optimum conditions. The selection of the optimum condition is focused on the highest desirability value (table 7).

Table 7: Solutions for $\mathbf{2}$ combinations of categoric factor levels

\begin{tabular}{lllllll}
\hline Number & Temperature & Times & Number & Yield & EGCG & Desirability \\
\hline 1 & 95.0 & 20.00 & Level 2 of C & 0.72202 & 294.182 & 0.949 \\
2 & 93.5 & 20.00 & Level 2 of C & 0.71262 & 278.389 & 0.865 \\
3 & 95.0 & 20.00 & Level 1 of C & 0.64091 & 293.544 & 0.860 \\
4 & 75.0 & 5.00 & Level 2 of C & 0.45353 & 278.888 & 0.559 \\
5 & 75.0 & 5.36 & Level 2 of C & 0.45692 & 275.168 & 0.552 \\
6 & 75.0 & 5.03 & Level 1 of C & 0.37273 & 288.719 & 0.423 \\
7 & 75.0 & 5.40 & Level 1 of C & 0.37620 & 284.611 & 0.422 \\
8 & 75.0 & 20.00 & Level 2 of C & 0.59658 & 204.895 & 0.349 \\
9 & 75.0 & 18.50 & Level 2 of C & 0.58228 & 204.653 & 0.340 \\
\hline
\end{tabular}
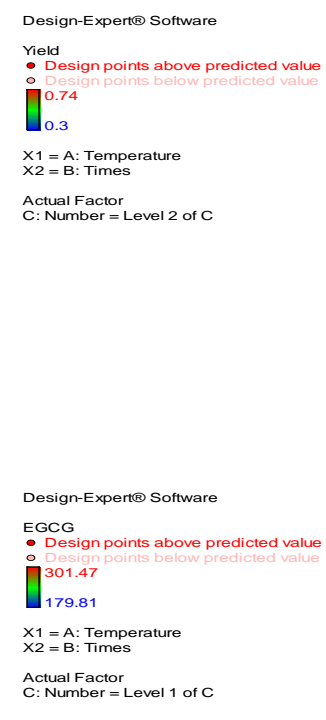

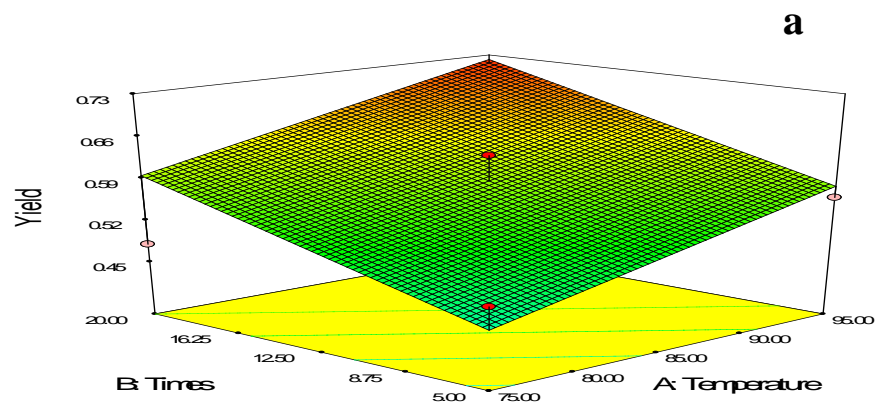

b

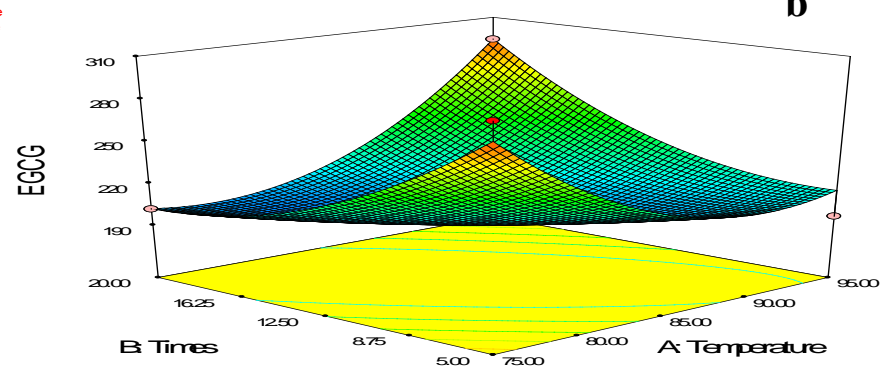

Design-Expert巴 Software

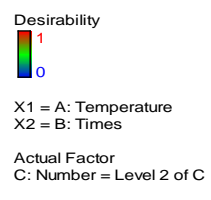

Fig. 3: Interaction factors A, B, and C on the extraction yield (a), interaction factors A, B, and C on the EGCG level (b), graphic of optimum extraction condition on the desirability value (c) 
The optimum condition was to use water temperature at $95^{\circ} \mathrm{C}$ with two-times brewing for $20 \mathrm{~min}$ (fig. 3c). The model predicted extraction yields and EGCG level of $0.72 \mathrm{~g}$ and $294.18 \mathrm{mg} / \mathrm{g}$. Meanwhile, the results obtained extraction yield and EGCG level of $0.70 \mathrm{~g}$ and $286.87 \mathrm{mg} / \mathrm{g}$. There were insignificantly different between predicted and observed ( $p$-value of the yield and EGCG level of 0.622 and 0.323 ).

\section{CONCLUSION}

The optimization process for green tea extraction has been evaluated. By CCD and desirability value, the optimum condition for optimum functional components in green tea extraction was $95{ }^{\circ} \mathrm{C}$ for water temperature, 20 min brewing time, and two-times brewing to obtain a yield of $0.70 \mathrm{~g}$ and EGCG of $286.87 \mathrm{mg} / \mathrm{g}$ dry weight.

\section{ACKNOWLEDGMENT}

This research was supported by Lembaga Pengelola Dana Pendidikan (LPDP) and Beasiswa Unggulan Dosen Indonesia-Dalam Negeri (BUDI-DN)

\section{AUTHORS CONTRIBUTIONS}

All author the author contributed equally

\section{CONFLICTOF INTERESTS}

The author declares there is no conflict of interest

\section{REFERENCES}

1. Perva-Uzunalić A, Skerget M, Knez Z. Extraction of active ingredients from green tea (Camellia sinensis): Extraction efficiency of major catechins and caffeine. Food Chem 2006;96:597-605.

2. Ramadon D, Pramesti SS, Anwar E. Formulation, stability test and in vitro penetration study of transethosoma gel containing green tea (Camellia sinensis L.) leaves extract. Int J Appl Pharm 2017;9:91-6.

3. Isnan AP, Jufri M. Formulation of niosomal gel containing green tea extract (Camellia sinensis L.) using thin-layer hydration. Int J Appl Pharm 2017;9:38-43.

4. Hajiaghaalipour F, Sanusi J, Kanthimathi MS. Temperature and time of steeping affect the antioxidant properties of white, green, and black tea infusions. J Food Sci 2016;81:H246-54.

5. Lambert JD, Kim DH, Zheng R, Yang CS. Transdermal delivery of (-)-epigallocatechin-3-gallate, a green tea polyphenol, in mice. J Pharm Pharmacol 2006;58:599-604.

6. Demir E, Serdar G, Sokmen M. Comparison of some extraction methods for isolation of catechins and caffeine from turkish green tea. Int J Second Metab 2015;2:16-25.

7. Banerjee $S$, Chatterjee J. Efficient extraction strategies of tea (Camellia sinensis) biomolecules. J Food Sci Technol 2015;52:3158-68.

8. Venditti E, Bacchetti T, Tiano L. Hot vs. cold water steeping of different teas: Do they affect antioxidant activity? Food Chem 2010;119:1597-604.

9. Vuong QV, Golding JB, Stathopoulos CE, Nguyen MH, Roach PD. Optimizing conditions for the extraction of catechins from green tea using hot water. J Sep Sci 2011;34:3099-106.

10. Lee JW, Mo EJ, Choi JE. Effect of korean red ginseng extraction conditions on antioxidant activity, extraction yield, and ginsenoside $\operatorname{Rg} 1$ and phenolic content: optimization using response surface methodology. J Ginseng Res 2016;40:229-36.

11. Sankalpa KB, Mathew SM. Response surface optimization of extraction parameters of green tea. Int J Agric Environ Biotechnol 2017;10:209.
12. Lee JW, Mo EJ, Choi JE. Effect of extraction conditions of green tea on antioxidant activity and EGCG content: optimization using response surface methodology. J Ginseng Res 2016;40:270-4.

13. Gadkari PV, Kadimi US, Balaraman M. Catechin concentrates of garden tea leaves (Camellia sinensis L.): extraction/isolation and evaluation of chemical composition. J Sci Food Agric 2014;94:2921-8.

14. Komes D, Horzic D, Belscak A, Ganic KK, Vulic I. Green tea preparation and its influence on the content of bioactive compounds. Food Res Int 2010;43:167-76.

15. N Politis S, Colombo P, Colombo GM, Rekkas D. Design of experiments (DoE) in pharmaceutical development. Drug Dev Ind Pharm 2017;43:889-901.

16. Martono Y, Martono S. High-performance liquid chromatography analysis for determination of gallic acid, caffeine, and epigallocatechin gallate concentration in various tea bags product. Agritech 2013;32:362-9.

17. Sugihartini N, Fudholi A, Pramono S, Sismindari S. Validation method of quantitative analysis of epigallocatechin gallate by high-performance liquid chromatography. Pharmaciana 2014;4:111-5.

18. Saito ST, Welzel A, Suyenaga ES, Bueno F. A method for fast determination of epigallocatechin gallate (EGCG), epicatechin $(\mathrm{EC})$, catechin $(\mathrm{C})$ and caffeine $(\mathrm{CAF})$ in green tea using HPLC. Ciênciae Tecnol Aliment 2006;26:394-400.

19. Setyawan EI, Rohman A, Setyowati EP, Nugroho AK. Application of factorial design on the extraction of green tea leaves (Camellia sinensis L.). J Appl Pharm Sci 2018;8:131-8.

20. Prabaningdyah NK, Riyanto S, Rohman A, Siregar C. Application of HPLC and response surface methodology for simultaneous determination of curcumin and desmethoxy curcumin in curcuma syrup formulation. J Appl Pharm Sci 2017;7:58-64.

21. Bezerra MA, Santelli RE, Oliveira EP, Villar LS, Escaleira LA Response surface methodology (RSM) as a tool for optimization in analytical chemistry. Talanta 2008;76:965-77.

22. Labbe D, Tetu B, Trudel D, Bazinet L. Catechin stability of EGCand EGCG-enriched tea drinks produced by a two-step extraction procedure. Food Chem 2008;111:139-43.

23. Wang H, Helliwell K. Epimerisation of catechins in green tea infusions. Food Chem 2000;70:337-44.

24. Krupkova 0, Ferguson SJ, Wuertz Kozak K. Stability of- $\nearrow$ epigallocatechin gallate and its activity in liquid formulations and. pdf. J Nutr Biochem 2016;37:1-12.

25. Liang H, Liang Y, Dong J, Lu J. Tea extraction method in relation to control epimerization of catechin. J Sci Food Agric 2007;87:1748-52.

26. Chen Z, Zhu QY, Tsang D, Huang Y. Degradation of green tea catechins in tea drinks. J Agric Food Chem 2001;49:477-82.

27. Vuong QV, Golding JB, Nguyen M, Roach PD. Extraction and isolation of catechins from tea. J Sep Sci 2010;33:3415-28.

28. Vuong QV, Stathopoulos CE, Nguyen MH, Golding JB, Roach PD. Isolation of green tea catechins and their utilization in the food industry. Food Rev Int 2011;27:227-47.

29. Yang DJ, Hwang LS, Lin JT. Effects of different steeping methods and storage on caffeine, catechins and gallic acid in bag tea infusions. J Chromatogr A 2007;1156:312-20.

30. Yu LX, Amidon G, Khan MA. Understanding pharmaceutical quality by design. AAPS J 2014;16:771-83.

31. Collins LM, Dziak JJ, Li R. Design of experiments with multiple independent variables: a resource management perspective on complete and reduced factorial designs. Psychol Methods 2009;14:202-24. 